\title{
Reading the Individual: The Ethics of Narration in the Works of W. G. Sebald as an Example for Comparative Literature
}

\author{
LAURA MARTIN
}

I

This history of this essay is a varied one, and its diverse origins will no doubt still remain visible in the final product. I shall allow the fissures to remain in the hope that by bringing a diverse set of questions and problems together in one place, I may allow them mutually to illuminate one another. The discussion is situated largely in the field of Comparative Literature and World Literature, in Damrosch's sense of literature read beyond its own borders, with specific reference to the German exilic writer W. G. Sebald; but the issues raised concern the wider and more urgent sense of a crisis in the humanities, not only in the UK but around the globe. The questions addressed here concern the possibility of reading or understanding an 'Other', whether by that one means an individual or, by extrapolation, a whole culture or society for whom the named individual is taken as a representative; the argument is pursued first in the context of modern languages and literatures departments under the threat of extinction in the English-speaking world, and then in the more particular context of teaching women's writing (or by extension any other 'marginal' writing) in such departments. However, the problems inherent in the attempt to 'read the other' are much more general-indeed universal. A non-Western, if not precisely postcolonial, context incites an acknowledgement of the seductiveness of self/other binary concepts, especially for those cultures which may be said not to have the same tradition of individualism and selfhood. Sebald provides the turning point: the Western European writer who depicts the failure of selfhood so dramatically that he may paradoxically inspire 
a model of moving beyond concepts of mutual alienation that seem to preclude empathy.

The first form this essay took was as a defence of a European Literature in Translation course to my colleagues in a department of modern languages. While teaching in translation is clearly not an equivalent of teaching in the original language, there are in fact several important advantages to it, one being its function as an antidote to the decreasing student numbers in our more traditional programmes. It is better to teach Kafka in translation than not at all. Moreover, knowing the language of composition does not in itself guarantee a better understanding of the author, of the text or of the culture under scrutiny. Not only do many language students fail to achieve an adequate level of comprehension of a literary text, some of them, particularly when confronted with a long or difficult text, do not even try. Many get by by reading the text in translation. Not all language students wish to be literary scholars, as much as we may regret it. Why not accept the fact and make a virtue of necessity by separating language teaching from literature?

But the issue needs pursuing beyond this pessimistic point: it is also true that, conversely, students well versed in the interpretation of literature, though perhaps lacking knowledge of the language in question, may have a completely adequate access into the literary text. Kafka might get a more insightful reading in an English Literature department than in a German one; moreover, we surely all know of important comparative or broadly laid-out critical works where the critic may read some of her texts in translation.

And finally: what calls itself the understanding or comprehension of an author or a text is at best a fiction of proximity. I may think I 'get' Kafka, and I may 'get' him better or worse depending upon, amongst other things, my language skills, but in fact the understanding is a subjective assumption. To argue, therefore, that Kafka read in English is a travesty is to falsely reify or idealize the relationship between reader and that which is read. This is by no means to argue that we should not continue to promote the learning of languages: it is to say that we can supplement our teaching programmes to cater to a wider audience, thus capturing more interest in the languages and cultures under question. ${ }^{\mathrm{I}}$

I next returned to this train of thought-about how a text written in a foreign language might be taught at a British university-when 
I gave a paper for a conference on women writers of the eighteenth and nineteenth centuries. This, to my mind, offered another chance for me to proclaim the advantages of my Literature in Translation course and to justify its existence: as student numbers in language departments decrease and student interest in and ability to read literature likewise plummets, the curriculum is becoming more presentist and more canonical: Kafka will almost certainly still be on the programme in most German departments for as long as they continue to exist; Goethe just might be; but Bettina von Arnim does not stand a chance. ${ }^{2}$ She does, though, on a comparative course of nineteenth-century women writers, or on a comparative course on political writing, or on fairy tales, for example. A German department might, certainly, have a course on fairy tales or political writing, but it gets ever harder to justify teaching material felt by the traditionalists to be marginal. There is more scope for such a wayward focus on so-called marginal topics on courses taught in English, as students can be expected to read that much more, unencumbered as they are with learning a foreign language.

The context of this piece of work was the sense of crisis in modern languages departments, and in the humanities in general. Whereas that sense of crisis has always been around from the inception of arts and humanities as programmes of study at universities in the early nineteenth century, ${ }^{3}$ the mood was worsening in 2008 when I wrote it, and indeed it has recently deteriorated further, as the 'economic downturn' champs down. As I write this, the British government is ending generally affordable tertiary education in England, and many universities, including my own (in Scotland), are closing departments. Modern languages have been some of the hardest hit units. My argument here is that even somewhat old-fashioned monolingual departments need to embrace 'theory' and interdisciplinarity in order to avoid going under. Clearly, many are already doing just this. And yet simply going global with your literary interests does not, in fact, solve the problem, as David Damrosch points out in his 'World Literature in a Postcolonial, Hypercanonical Age'. ${ }^{4}$ In the context of World Literature, a single author may end up representing a whole nation or culture in 'some literary Miss Universe competition' (Ibid., 48). For Damrosch this applies to World Literature representatives from countries other than Western Europe and North America-but will Germany remain, for practical purposes in academic departments, a 'canonical country' for speakers of English for much longer? And it hardly solves the problem of getting 'marginal' writers in European traditions read: rather, fewer and fewer 
writers are being read on the world stage. This reverts to the 'Kafka represents Germany' problem mentioned above. ${ }^{5}$ Meanwhile, according to Damrosch, even traditional English Literature departments in the English-speaking world have a similar problem: the demolition of the canon and the rise of theory have nudged 'marginal' writers from the curriculum. We are no longer united as academics in our knowledge of the Metaphysical Poets or the Romantics, major and minor, but of 'Butler, Foucault, Said and Spivak' (Ibid., 44). With little time left over for the primary texts, we may still read 'Shakespeare and Joyce' - the 'hypercanon' - but lose track of 'Hazlitt and Galsworthy' (Ibid., 46). Still no hope for Bettina von Arnim, then, or even for her brother Clemens Brentano and her husband Achim von Arnim, all minor but nevertheless important writers.

Thus the problem is not a consequence simply of the linguistic narrowing of the British and American public, but a more general one. The opening up of the curriculum or the demolition of the canon, however you choose to call it, predictably led to a loss of certainty about what was important to teach and to know: this has effects both positive and negative. We are left with the 'hypercanon' and the dirigiste theorists; if you are feeling adventurous, add a few World Lit texts to broaden your horizons - Things Fall Apart and Beloved (Ibid., 5o), and you are done. It is not that we know more and more about less and less, but that we know less and less about less and less. This, I hope, is far too pessimistic a formulation, but still the issues must be faced: whether we are teaching the literatures of our own culture(s) or foreign one(s), it is not clear how to package our cultural past (or should we be focussing on the present?) in the best possible way.

And the final impetus to think through the topic of the (im)possibility of reading and representing the foreigner, the Other, or simply 'an other' was also, perhaps sadly, a negative one. It was a formulation in the CFP for an otherwise highly interesting conference that was disturbing. The admirable admonishments in the description of the session at the ICLA in Seoul, Korea, in August 2010 asked us to move 'beyond the boundaries of ethnicity, culture, region, politics, and scholarship to expand [... Comparative Literature's] horizon', and to '[breach] the fence of Eurocentric literary theory and discourse'. Who could argue with such worthy goals? What is worrying, however, is, first, the enjoinment in the first phrase also to 'unify' this horizon, and the subsequent call to 'canonis[e] the long-standing and tenacious literary traditions of other regions' ${ }^{6}$ While acknowledging the value of the first-cited aspirations, 
I argue that such unification and expanded canonization are precisely not what is needed for Comparative Literature at this time.

What partially unifies these diverse essays is the difficulty we face as educators - or indeed simply as readers ourselves - to represent adequately an Other to ourselves or to our students. But the Seoul call for papers makes apparent our continuing reliance on just such simplistic ideas of an allegedly unified culture that can be deputized by the best and most representative creators and producers of literature, politics or art, etc. Whilst we in the Western world (supposedly) know perfectly well that Culture, big-C, is simply a (bourgeois) construct, and canons are best shot down, we cannot help ourselves. We cannot teach everything, we must be selective, and so we try to choose what will lead to the greatest or best understanding of whatever it is we think is our subject: a country's culture, its language, its history and politics, generic skills in literary analysis, according to our taste. The Korean CFP has the merit of stating it more honestly than we Westerners tend to do these days.

This essay will focus on the last of the three stages of its inception. I have spent so much time on the history of the writing in order to bring out the pragmatic and practical side of the problems raised here: far from wanting to tell our Korean colleagues how they should or should not propound a sense of their own national or regional identity through the creation or suppression of a literary canon, I wish to use this trigger as an incitement to discuss matters closer to home. I shall first discuss how the disciplines - or 'indisciplines' - of Comparative Literature, World Literature and Post-Colonial Studies, in particular the insights of Gayatri Spivak and David Damrosch - can help us theorize canons and Others. Next, the 'prose narrative' Die Ausgemanderten (The Emigrants) by the German exilic writer W. G. Sebald will be discussed as an example of 'narrating the other' - or rather, conversely, as an exemplification of the very impossibility of narrating anything but oneself. Emmanuel Levinas, C. G. Jung, Peter Hallward and a few others give me the tools to discuss the ethical imperative though practical impossibility to grasp the Other without imposing or indeed colonizing.

3

My quibble with the Seoul ICLA Call for Papers was about the enjoinment to create new boundaries and new canons in the East in order to replace the more or less colonial impositions of the Western canon on literary and academic thought and writing there. We find ourselves in a 
highly ambivalent position: canons can provide a focus for attention, yet their unfairness and exclusivity is intrinsic. This ambivalence in regard to the concept of the canon seems to shine forth from the CFP itself, which hovers precariously between admonishing, on the one hand, to expand boundaries and yet, simultaneously and paradoxically, to build walls and canonize on the other.

The CFP's issue-taking with Western theory ('[breach] the fence of Eurocentric literary theory and discourse') merits further attention. A paradox has emerged repeatedly since the dawn of the post-modern age: post-modern theory is both as Eurocentric as it is often accused of being, and the exact opposite: it is, certainly, blind to the otherness of other traditions; yet the famous decentring it enjoins and performs opens Western theory up, potentially, to complete acceptance of all others precisely through its dismantling of the (Western?) self. Postmodern Western theory says there is no solid 'self' that could escape the dismantling power of deconstruction; this would seem to pre-empt the Seoul CFP call for a new identity-formation for the Eastern world. Post-modern theory thus paradoxically alienates and excludes by its very claim to have the final word on the matter; having just told us there is no final word, no ultimate signifier, it claims that this is the final word on the matter. This problem, seen here in the Korean CFP, continues to play itself out in the postcolonial realm as well as the feminist one; it was present from the start in the I970s when Anglo-American feminism fought it out on the battlefield of hopeful identity politics in opposition to the despairing philosophy of deconstruction and its infamous 'hermeneutics of suspicion'. American feminists were trying to assert a right to speak with 'woman's voice' precisely at the same time the postmodernists were denying any possibility for there to be an individual to have a voice (other than a postmodern one).

Comparative Literature can provide methods and venues for subverting the simplistic equation of nationality or ethnicity (or gender) with identity. ${ }^{7}$ Important works in the last decade about the role and status of Comparative Literature have emphasized the provisional nature of the field itself, what might be called its 'lack of discipline' or lack of a centre. There can be no canon of Comparative Literature, even if one substitutes the term 'World Literature' instead: the field is simply far too enormous for anyone to make any even moderately valid claims to know which works are the right ones, and how they are best aligned in a system of other works. Thus, one finds comparatists arguing for provisional, partial, contingent formulations of the object of study. Moreover, there 
is also a strong argument for considering Comparative Literature as inherently theoretical and postmodern: Gail Finney, a Germanist from the US, says, to take one example: 'The anti-essentialism of Nietzsche and Derrida links deconstruction and other modes of poststructuralist thought to comparative literature, in which the tendency has long been to question traditional boundaries, to open up literary genres and traditions, to test traditional definitions. So it is possibly for this reason that many comparatists have been more receptive to poststructuralist thought than have scholars of individual national literatures'.

Gayatri Chakravorty Spivak announced, in Death of a Discipline (2003), ${ }^{9}$ the death of Comparative Literature as we then knew it - the Eurocentric, largely French, German, and English-focussed paean to the culture (or cultures) which came so close to doing themselves in, several times, in the course of the twentieth century. Her argument is with the specifically US institution of Comparative Literature, which, growing out of the brain influx of cultured Europeans in the I930s and I940s, established itself as the defender and champion of European culture at a moment when Europe itself seemed en train to wrecking itself entirely. She calls rather for Comparative Literature to be done much more widely, much more inclusively and much less prescriptively. Spivak's other bete noire is US Area Studies: the study of so-called 'minority' languages in order to get a cultural purchase on geographical areas in which the US government (i.e. military) and/or businesses have an interest. Spivak wants us to blend the best of both: we should constantly open ourselves to new minority languages (as Area Studies does) and their literatures (like Comparative Literature).We can read in translation, but also should make the effort to learn the language, however impossible it will be to learn many of them to any level of expertise. It is an imperfect project, and in no way perfectible: but the journey itself is the goal. Cross borders constantly, she admonishes us; approach the 'Other' even if there is no way ever to 'arrive', in other words to come to know the 'Other'. Spivak's phrase is that such knowledge is always 'to come', never already here. The constant endeavour to understand ever more 'Others' is a salutary reminder that we are always caught short in our compassion. Moreover, Spivak, a follower of Jacques Derrida, thus bridges already any neat distinctions between (bad, exclusive) Western theories and a new Comparative Literature that is open-minded to non-Western ways of being.

At first blush David Damrosch seems to give us an entirely different perspective in his What Is World Literature? (2003). ${ }^{\text {IO }}$ Damrosch comes 
from the kind of tradition Spivak so deplores-English Literature and Comparative Literature; but his project is not altogether different from hers. World Literature, Damrosch says, has three defining characteristics: '(I) [it] is an elliptical refraction of national literatures; (2) [it] is writing that gains in translation; and (3) [it] is not a set canon of texts, but a mode of reading: a form of detached engagement with worlds beyond our own place and time' (28I). One can immediately see here the contingency and non-perfectibility of Damrosch's project, with the emphasis again placed on the journey, not the outcome. He, too, escapes the unnatural confines of so-called national literatures: sallying forth into the World realm helps us to a better understanding of the national literatures we come from, through what he terms the 'elliptical refraction'. We should in fact come back to our home turf now and again, an imperative which the decidedly more peripatetic Spivak would not be likely ever to give us. In his second point, Damrosch brings us to another discipline, Translation Studies: a work may live a continued life, a new life, or a different life in another culture, and (à la Walter Benjamin, who said it first in his 'The Task of the Translator') ${ }^{\mathrm{II}}$ this is by no means a second-rate existence. More border crossings, from this culture to that, and from the original to that very different beast, the translation. Lastly, for Damrosch, the canon is not where it is at: his 'mode of reading' sounds awfully like Spivak's call to leave home although we will never arrive at any 'there', at the place of any 'Other'. He humorously invokes Dr Doolittle's double-headed llama, the Pushmi-pullyu, always going in two directions at once. This is a disavowal of all our favourite binary oppositions: self/other; nation/world; general/specific; learning languages/learning literatures; our specialist areas of study/our bold ventures into World Literature.

What is similar in these two suggestions for Comparative Literature's future is the flux and flow of the knowledge of a particular comparatist and the uniqueness of this individual's engagement with languages, literatures and cultures. Moreover, each acknowledges a provisionality of this knowledge: as in Homi Bhabha's concept of the Third Space, there remains a bridge that can never be completely crossed. Lastly, all three-Spivak, Damrosch and Bhabha-acknowledge that the source culture of the observer must always play a role: there is no escaping it into some realm of universal comprehension. The corollary conclusion seems in the offing that this difficulty is not only encountered when cultures are being crossed, but always and everywhere, so that reading in one's own native language requires a similar acknowledgement of subjectivity. 
In order to discuss how it is through the particular that we can gain at least a modicum of understanding of others, I shall take as my case study the work by the German exilic writer W. G. Sebald, focussing on one book, Die Ausgemanderten: Vier lange Erzählungen (1992) (The Emigrants [1996]), with reference to two others: Schmindel. Gefühle. (1990) (Vertigo [1999]) and Austerlitz (200I) (Austerlitz [200I]). ${ }^{\mathrm{I2}}$ It is not particularly that Sebald should be held up as a model to follow so much as that the problem thrown up by the interpretation of his works - including some difficult ethical dilemmas - may point the way forward for a discussion.

Sebald has, in the last decade and a half, taken the world by storm. There is something both magnificent and compelling about the way this writer struggles to redeem from the smouldering ashes of a bombedout Europe a sensitivity and ethical integrity, despite a concomitant deep despair and melancholy. Growing up in southern Germany just after the end of the Second World War, Sebald was deeply frustrated at the dearth of histories, truthful account-making, or remembrances of wartime. ${ }^{13}$ Emigration to England as a young man in the mid-r96os seems to have provided the necessary distance for him to thrive and to ponder productively; only in his middle age came the 'prose narratives' ${ }^{\prime 4}$ in which an unnamed narrator (though generally implied to be Sebald himself) recounts second-hand the tales of exiles and wanderers on the face of the earth.

The state of melancholy is one of isolation: it is the despair at there not being any meaning to comprehend or anyone whom one could share any meaning with. And yet, Sebald continues to communicate, and indeed to draw from other melancholics their tales, their stories. Each tale is a remembering, and yet remembering seems proved useless, as these stories are all belated; they are second- or even third-hand; and they are woefully inadequate to the task of redeeming each individual's suffering. Each tale enacts the construction of an identity and a past, and yet identity is shown to be so fragile as to be itself meaningless: easily shattered, mostly misrecognized, never entirely to be understood by another. And yet - Sebald writes.

\section{DIE AUSGEWANDERTEN (THE EMIGRANTS)}

The four individuals Sebald's narrator ${ }^{15}$ represents in this 1992 'prose narrative' are all outsiders, oddballs, eccentrics, melancholics; three of 
them are men he has met and one is his ancestor; his investigations into their tales are apparently inspired by a curiosity and will to understand kindred spirits from an earlier generation. Dr Henry Selwyn is his landlord in England: he transpires to be a Jew from Lithuania who emigrated when only a small child. Paul Bereyter was Sebald's primary school teacher; he, too, was Jewish, or part Jewish, and was forced to flee the Nazis, yet returned after the war to his and Sebald's hometown. Ambros Adelwarth, Sebald's great-uncle, had emigrated to the US when Sebald was still small. It is never said openly, but Adelwarth's tribulation was presumably his homosexuality. Lastly, Max Ferber, a painter the young 'Sebald' ${ }^{16}$ meets in Manchester when he comes to England as a language tutor, had been sent by his parents on one of the Kindertransporte to school in England in the I93os shortly before they were deported and killed in the concentration camps.

Three of the four tales end in suicide: Selwyn uses the hunting gun he never used in India as a young colonist, Paul Bereyter lies down on the tracks outside of the town where he had lived and worked - we are shown a picture of the exact curve in the tracks where it happened. Most horribly, Ambros Adelwarth willingly allows himself to be institutionalized in a sanatorium where he will undergo a long course of electrotherapy which he must know will eventually kill him.

Throughout, we have highly moving, yet strangely ephemeral accounts of the lives of normal, everyday people who have been more or less destroyed by the sweeping events of the twentieth century. Disaster and catastrophe, both of a personal nature as well as due to social and historical change, are always the subject of these bleak yet nostalgic narrations. The tales all end in despair; there is never any neat wrapping up. There is certainly never any mythologizing into heroic packaging. The losses these people have sustained seem senseless, futile, and are possibly the result of a malign and vicious order of things. The characters are shown to be human and deserving of compassion, but they are never improved or purified through their trials and tribulations. Nor is it apparent that the reader is thus 'improved' through reading about them.

Here, as in the earlier Schwindel. Gefühle. and later Austerlitz, 'Sebald' tells other people's stories, often mixed in with the narration of his encounters with the individuals as well as of his own investigative journeys. They are often mediated by at least one other interlocutor: 'Sebald' talks to Selwyn's wife about Selwyn, to his townspeople as well as Bereyter's mistress about the teacher, to his Aunt Fini and later to the disillusioned former psychiatrist at the sanatorium in Ithaca, New York 
about his great-uncle Adelwarth, and his account of Ferber is rounded by the inclusion of Ferber's mother's memoirs of her childhood. And they are highly personal, one might almost say, invasive: we have family photos, journals, a mother's childhood memoirs, suicide notes. We hear of dreams and fantasies, and many personal details usually left out of public memoirs. The interlocutors and their representatives apparently volunteer diaries, photographs, letters and other personal memorabilia to the narrator to make use of as he will. He is given an unusually free hand, in all cases. Photographs and facsimiles of important documents interspersed in the text lend a feeling of concrete reality.

And, on the other hand, the narratives are also always highly personal to the narrator (and to the author?), too: he is a hovering presence in all the narratives, an almost journalistic investigator who, in unjournalistic fashion, seems to take a very personal interest in these tales. Somehow, 'Sebald' is always actually investigating himself as much or more than he is investigating an Other. This results in a strange mixture of narrative voices: the reader is not always sure who is speaking, as inverted commas are never used, and even the sporadic use of the German indirect discourse subjunctive is not always enough to make this clear. One example can show the complexity of the narrative layering: the chapter on Ferber actually starts as a narrative about 'Sebald's' move to Manchester; Ferber's oral narration to 'Sebald' is thus set in a time and place of 'Sebald's' own biography. An early narration from when 'Sebald' is twenty-two is supplemented by a later narration, when the middle-aged 'Sebald' returns to track this man down again and find out the real story; this in turn is supplemented by the memoirs of Luise, Ferber's mother. Incredibly, Ferber willingly gives this important document to his biographer. Now this merges back in with 'Sebald's' life: he travels to Kissingen and Steinach, where Luise grew up, in search of lost time, but fails to find it; instead he rues the post-war German tendency to eradicate all evidence of history, at least of twentieth-century history. That, of course, is 'Sebald' speaking, not Luise and not Max Ferber, but all parts of this highly complex narration-within-narration, even the parts not ostensibly in the voice of the character 'Sebald', are told in the same ironic-nostalgic tone with the same whimsical humour: Sebald's humour. The confusion of voices is, then, caused by more than the sameness of orthography and grammar: the voices are all somehow very much the same, when even Ferber's mother speaks, as a young woman, with 'Max Sebald's' voice, noticing the kinds of things he notices, making the same sort of ironic-tinged-with-melancholy commentary. 
This merging, segueing, imbricating happens on yet one more level, one that might seem almost supernatural or determined by suprahuman forces of fate: the interconnections between biographies are interwoven with alarming coincidences: 'Sebald' is twenty-two when he arrives in England and meets Ferber - who says he has lived there twenty-two years. Bereyter was 'about 22' when he first emigrated from Germany. 'Sebald' goes to live in Switzerland to fulfil the dream of being a teacher there-in the earlier chapter, Paul Bereyter is said to have been a schoolteacher in Switzerland. In a truly bizarre fashion, Vladimir Nabokov makes an appearance multiple times in Sebald's oeuvre - as a boy or man seen catching butterflies in a field, a text being read by a character at a crucial juncture, etc. 'Sebald' just happens to be travelling through Switzerland when the body of Selwyn's mentor Johannes Naegeli, an avid mountaineer, is discovered many years after his disappearance, and he just happens to read the article on the train going through the Alps. There are many, many more such strange overlappings between the individuals' tales.

In an interview, Sebald slyly admits that he fakes: there is no 'Max Ferber': this story is a mixture of the tales of at least two individuals; though the newspaper article describing the discovery of a mountaineer's body is real enough, the identification with Selwyn's friend is not; the many appearances of Nabokov are of course whimsical additions. More shockingly, Adelwarth's suicide note (his calling card with 'Have gone to Ithaca. Yours ever, Ambrose' - an Odyssean statement, if there ever was one-handwritten on it, left for his sister Fini), and many of Adelwarth's journal entries are in fact faked. Sebald says that 'ninety percent of the images inserted into the text could be said to be authentic' (emergence, 4I). That means that ten percent cannot even 'be said to be', of course. It is not clear just what percentage of the narratives are authentic, although Sebald assured his interviewer Eleanor Wachtel that ' $[\mathrm{t}] \mathrm{he}$ stories as they appear in the book follow pretty much the lines or the trajectories of these four lives as they were in reality. The changes I made $[. .$.$] are marginal changes, changes of style rather than changes of$ substance' (emergence, 38 ). ${ }^{17}$ But the reader does not know what counts as 'marginal'.

What is the reader to make of this? Perhaps it is shocking: the author Sebald appropriates others' stories; he wilfully embellishes these stories to make them seem more connected to the life-story of the narrator and to each other; stylistically, the distinction between narrator and interlocutor 
is deliberately blurred to the point of confusion to the less-than-vigilant reader. One critic calls Sebald (the person) 'Zelig-like', ${ }^{8}$ reminding us of the Woody Allen film character that takes on the personality of everyone around him, becoming by turns a Hasidic Jew, black jazz musician and whomever else he chances to meet. A near-total self-effacement enables the other to be manifested vicariously. Is this what the narrator 'Sebald' is doing, too? It is true that we never have a straight autobiography of W. G. Sebald himself; but in fact his method in his writing is precisely the opposite of self-effacement: the Other is always mediated through the ubiquitous Sebaldian narrative tone and voice. It is the Other that disappears, either instead of or along with Sebald himself. The life events of Bereyter and Selwyn, Adelwarth and Austerlitz, Beyle and Kafka-i.e. the protagonists from throughout his oeuvre-vary, but only in detail, and never in tone and mood. It all becomes, somehow, one vague, generalized life story, not owned by any one individual.

In a way, this method of narration is simply honest: Sebald does not maintain the fiction of objectivity, but rather he makes no bones, apparently, about telling another's story through his own voice without the pretence of really speaking for or as the other. But this is still a problem: after all, he does use first-person narrative, he does, in fact, pretend the other is speaking. As one critic put it, 'The strangest thing about Sebald's incomparably strange work is that upon first reading it gives us no reason to think that it is fiction'. ${ }^{19}$

Sebald describes Ferber in his dimly-lit studio, nearly buried in the dust and scraped-off paint from his many attempts to paint portraits. Apparently eschewing physical light, Ferber worries that he can never quite catch the eyes and faces of his subjects, and so he scrapes off the paint, driving his models to distraction with his multiple attempts. 'Sebald' repeats this, citing his own ethical qualms about telling Ferber's story: can he get it right? This is an admission that you cannot reach, touch or understand the other person. You can only allude, bind by association, and communicate vaguely about even the most real events, even when you provide (seemingly) clear, concrete photographic evidence.

And yet, despite this apparently genuine expression of his qualms, Sebald has, in fact, aestheticized the suffering of others and sold their stories for personal fame. Where Sebald writes most transparently he nevertheless is most opaque, just as, conversely, the simple, almost dry tone of voice belies the most horrendous and horrifying events. He tries, 
and fails, to pick up the pieces of a vanished past; he questions his interlocutors too little, too late, and usually asks some of the important questions only after their deaths. And a lot of it is simply made up, anyway.

Is there any other way?

\section{CONCLUSION}

For Sebald, personal, private idiosyncratic histories of exile and melancholy seem to give access to others through their twice-narrated memories and lead to the recovery of shared history. It is, in fact, in their uniqueness that these tales gain authority over our compassion; and yet, paradoxically, the tales are all bizarrely similar, and so it is (also) by means of almost uncanny repetition within them that we become increasingly moved: yet another, and yet another, and yet another sensitive male soul whom history or mankind or fate has worn down to a shadow existence. Strangely and paradoxically, it is the uniqueness of the author Sebald's own take on these tales that makes his works compelling reading: not Selwyn's, Bereyter's, Adelwarth's and Ferber's stories, but the tales of Sebald's Selwyn, Sebald's Bereyter, Adelwarth and Ferber. Moreover, Sebald explains why he felt compelled to trace these lost histories: reading of the demise (by suicide) of the writer Jean Améry, Sebald realized he knew of similar tales of long-suppressed trauma resurfacing with deadly consequences in old age. ${ }^{20}$ By tracing them, he began the task of understanding his own personal and national history in a way not in the least enabled by the impersonal if horrifying post-Holocaust films he was shown, without comment, at his school in Germany. ${ }^{21}$ He makes these others' tales quite literally his own, in more ways than one, in order to understand as much as he can about their histories, his history and our history.

The paradox is complex: by telling us these tales, Sebald allows access to the stories of otherwise completely forgotten 'little people', the individuals whom the great machinery of history churns in its maw. By telling the tales in his own voice and with his own plot embellishments, he erases their individuality: we are in fact only hearing about one individual, Sebald -or 'Sebald'. But this appropriation of the other's story is precisely what connects two individuals, and it is what allows some modicum of 'universality' as an idea to sneak in. We are no longer united by our shared past and a home we can literally return to, but by our shared narratives of increasing alienation and isolation - thus it seems 
Sebald is telling us. A European, Western-world narrative it is, one told over and again ever since the Enlightenment and more urgently since the catastrophes of the twentieth century. There is, apparently, no going back.

The character Austerlitz in the novel of that name has a fascination with the architectural structures of the past, in particular train stations and fortresses: those structures, on the one hand, which allow 'traffic' between individuals (or else take us away from one another and from our own pasts) and those, conversely, which would protect us from foreign invasion (and which keep us confined in one space). All of the fortresses described fail, sooner or later: you cannot prevent invasion forever. The train stations are alternately overly-ornate relics from the past, modern cheesy hubs of hectic activity, or in one case, a ghost-filled shadow-form of a repressed trauma. You cannot connect - neither with others nor with your own past - but nor can you escape from these either. He who would be 'an island unto himself' is the Scylla, he who would commune and connect the Charybdis, on our own attempted journeys back to Ithaca, where we once belonged before we began our individual Odysseys. ${ }^{22}$

Like Rumpelstilzchen of the German fairy tale, the nations of Europe tore themselves in two in the twentieth century: imitating, perhaps, that little gnome who thought he could, by his own hard work and a little skill in magic, buy beauty and youth in the form of a young maiden. Postenlightenment, post-romantic, post-modernist Europe fell into a selfdestructive rage when it transpired that all our new-fangled virtues - the hard work and graft of our secularized work-ethic religion together with the magic of our scientific progress - were not leading to permanent happiness. We sought happiness by striving, acting, working to create our own individual space within the world: each man for himself, then each nation against the other. Religious and nationalistic affiliations which seemed to reunite the solitary being with something bigger revealed themselves to be an amplification of the problem only, not its solution. And yet now, in the form of a Call for Papers at a Southeast Asian conference, and in much that has been written in the last two to three decades in post-colonial studies, we are hearing new calls for new group identifications from other peoples.

This terrible history of the West can be a reason for despair, quite obviously, but it can also be a means to a further insight: if not exactly optimism at least a cheerful fatalism. Levinas tells us both that we can never actually have 'knowledge' of the Other but that we must nevertheless try (something Spivak seems to echo). The failure of 
understanding is not necessarily a failure of compassion, and is not a cause for giving up: it is a sign of the respect for difference, after all. ${ }^{23}$ C. G. Jung - unlike Freud in his worst moments - fully acknowledged that (even) the analyst, who knows the most intimate details of the patient, still cannot ever fully interpret the dream. Symbols that obtain on an archetypal, universal level, according to Jung, still have validity and meaning for the individual only in a highly idiosyncratic, unique way, and even the expert has no fool-proof access. This, too, represents a failure to connect. However, the patient him- or herself also never fully understands, consciously, the meaning of the dream, as it is simply not accessible to the conscious intellect. So, conversely, we are not so individualized as we thought, then, not even through Jung's process of 'individuation'. The paradox is that this connection with others and with - what? 'Nature'? The 'Universe'? - is indicated by our collective inability to interpret fully by means of our intellects. The connection is of a different order or class than the intellectual.

In our post- poststructuralist age, the time has come again to see ourselves not simply as separated, isolated beings, but to accept the paradox of our aloneness within connectedness. Concomitantly, we must hold the balance between possibilities of self-determination despite all the immoveable factors such as genetics and socio-historical reality that give us our in-born make-up. These questions are, clearly, not new: Knox calls it 'the freedom of the dog tied to a cart' in his discussion of the idea of Fate in Greek tragedy. ${ }^{24}$ We are both determined and free, separate and together. The work of Hallward in post-colonial studies is another case in point: his distinctions between the singular, the specific and the specified represent an attempt to allow for individual freedom and self-determination somewhere between monadic isolation and social-cultural or ethnic predetermination in such a way as to be able to talk about universal values or truths which are based on contingent accident. ${ }^{25}$ Meanwhile, there is a growing body of work bringing Eastern and Western philosophies and psychologies together, for example Mark Epstein's work which produces new insights into the nature of an 'ego' which is apparently not universal in its manifestation. ${ }^{26}$ The last decades have brought us, then, more than the dismal sciences of deconstruction and dog-eat-dog economic collapse. To build on this and return to an earlier preoccupation of this paper: the rapprochement between East and West can happen in very different ways than seem to have been implied in the CFP I have taken such exception to, where the East seems invited to repeat the failures of the West. 
To my mind, Sebald does not quite show the solution: he shows us the final frontier of the problem - people on the brink of the abyss. From Adelwarth to Austerlitz, they embody the futility of self-reliance and self-determination. It is something, perhaps, those Eastern religions and philosophies have long known about. If Adelwarth can write 'have gone to Ithaca' on his visiting card as the most succinct suicide note possible, we can, perhaps, take this as a sign not only of desperation and giving up, but also of a more mature giving in and accepting the inevitable: the extinction of the self. It may not be possible for us to make it back to some mythical 'time before', the good life with Penelope, that predates our current existence on the battlefield of life, but we do all eventually make it home to a different feminine principle: the womb/tomb. Indeed, our Western disease inheres precisely in our pretence that we can overcome mortality by sheer willpower. Unwittingly, perhaps, Adelwarth has rewritten that epitome of the Western life-journey in a way more comprehensible to the mind trained in Eastern philosophies than the Oedipus myth: not a guilt-ridden replacement of the father for our heroic ego, but the Odyssean return to the source.

Where does this leave us? The psychological detritus of post-war Europe that Sebald shows us in such a harrowing fashion functions as a metaphor of modernity. The 'discipline' of the nineteenth century, and our Western development of a strong sense of self and of the intellect have not proven to be entirely beneficial to the world (to say the least). As an example for Comparative Literature - my title for this essay-Sebald gives us a depiction of the Western, alienated soul who nevertheless always still reaches out. His characters are old, superannuated men who have experienced severe ruptures in their life-stories and a loss of connection to community and to the past, yet their stories, even secondhand, are compelling. We learn from them, though it may be hard to say just what. Now, as we face the closures of university departments and indeed even whole universities, and in particular the loss of humanities subjects, perhaps we might take some of Sebald's energetic (although melancholic) drive to narrating the Other: if we want to survive, we need to defend rigorously our task to search out other times, other peoples and other places and 'tell their stories' (if in our own words) in our teaching and academic work, though governments and university management teams tell us we are worse than useless. Nor should we allow ourselves to be immobilized by our own sense of futility as we face loss and change. However we go about our engagement with the Other(s), in whatever language, we must persevere. 
Far from coming up with a solution, I have used the example of Comparative Literature in its association with Post-Colonial or at least non-Western contexts to discuss self, other and the concurrent imperative, if impossible, burden to approach the Other.

\section{NOTES}

I Indeed, Classics departments in the UK faced this dilemma, two to three decades ago, and successfully solved it by providing degree programmes in Classical Civilisation, with no language skills required.

2 The conference 'Women Writers of the Eighteenth and Nineteenth Centuries' was held at Exeter College, Oxford, in August 2008. Other participants bemoaned the disappearance of women writers from curricula in British and American German departments, and even in German universities.

3 See, for example, John Guillory, Cultural Capital: The Problem of Literary Canon Formation (Chicago: University of Chicago Press, 1993).

4 David Damrosch, 'World Literature in a Postcolonial, Hypercanonical Age', in Comparative Literature in an Age of Globalization, edited by Haun Saussy (Baltimore: Johns Hopkins University Press, 2006), pp. 43-53.

5 A claim which is all the more ironical, of course, since Kafka was a Czech Jew.

6 ICLA Call for Papers for the conference held in Seoul, South Korea in August 20I0. The cited portion of the CFP was for Session I: Making Comparative Literature Global: New Theories and Practices. It was still available at this site on 5 December 20 I I $<$ http://encls.net/?q=event/xixth-congress-internationalcomparative-literature-association-20 Io-seoul-conference $>$.

7 Indeed, discussions of the roles and functions of Comparative Literature are ongoing, and it is not possible to refer specifically to many informative sources. See Charles Bernheimer, ed. Comparative Literature in the Age of Multiculturalism (Baltimore: Johns Hopkins, I995); Saussy Globalization; as well as various articles in Comparative Critical Studies, 3. I-2 (2006), for instance.

8 Gail Finney, 'What's happened to feminism?', in Saussy, Globalization, pp. I I4-I26 (p. I I 7 ).

9 Gayatri Chakravorty Spivak, Death of a Discipline (New York: Columbia University Press, 2003).

Io David Damrosch, What is World Literature? (Princeton: Princeton University Press, 2003). Amusingly, Spivak and Damrosch were colleagues at Columbia at the time both these books were published.

I I In Illuminations, edited and with introduction by Hannah Arendt, translated by Harry Zorn (London: Pimlico, 1999), pp. 70-82.

I2 Die Ausgemanderten: Vier lange Erzählungen (Frankfurt a.M.: Eichborn, I992), translated by Michael Hulse as The Emigrants (London: Harvill Press, 1996); Schmindel. Gefühle. (Frankfurt a.M.: Eichborn, I990), translated by Michael Hulse as Vertigo (London: Harvill, I999); and Austerlitz (Munich: Carl Hanser, 200I), translated by Anthea Bell as Austerlitz (New York: Random House, 200 I). 
I3 See especially Luftkrieg und Literatur: Mit einem Essay zu Alfred Andersch (Munich: Carl Hanser, I999); translated by Anthea Bell as On the Natural History of Destruction: With Essays on Alfred Andersch, Jean Améry and Peter Weiss (New York: Random House, 2003) as well as the interviews in the emergence of memory. Conversations with W. G. Sebald, edited by Lynne Sharon Schwartz (New York: Seven Stories Press, 2007).

I4 'Prose narrative', 'prose fiction' and 'documentary fiction' are some of Sebald's own terms for his innovative narratives (emergence, p. I6 and p. 37, and p. I03 respectively).

I5 Sebald's narrator shares many biographical details of the historical Sebald. In the interests of clarity, the narrator will be called 'Sebald' (in inverted commas) in this discussion of Die Ausgemanderten to distinguish him from the author Sebald (referred to without inverted commas). The four subjects of the Erzählungen (stories) are also mixtures of fact and fiction, as we will see further below.

I6 The difficulty of distinguishing author and narrator in the discussion is already proving difficult: as the previous three interlocutors: Selwyn, Bereyter and Adelwarth, are real people (though at least one is given a pseudonym) whom Sebald really did interview and investigate, it is fair to speak of the author in this context; as 'Ferber' is a conflation of two individuals, I can only refer to a fictional 'Sebald' as reporting on him. See 'Ghost Hunter', an interview with Eleanor Wachtel, in emergence, pp. 37-6I.

I7 See also his interview with Carole Angier, 'Who is W.G. Sebald?', in emergence, pp. 63-75 (pp. 73-74).

I8 Lynne Sharon Schwartz says this in terms of the author as interviewee, not as author per se. 'Introduction', in emergence, pp. 9-22 (p. I 8).

I9 Ruth Franklin, 'Rings of Smoke', in emergence, pp. I I9-I43 (p. I22).

20 emergence, p. 38.

2I Joseph Cuomo, 'A Conversation with W. G. Sebald', in emergence, pp. 93-1 I7 (p. 105).

22 It is all the more poignant in that Sebald's work may be described as the attempt of the post-war German to understand the Jew who was eliminated or driven from his country before he was born; railroads become fascinating for much more horrifying reasons. See Cuomo, 'Conversation'.

23 Emmanuel Levinas, 'Is Ontology Fundamental?', in Basic Philosophical Writings, edited by Adriaan T. Peperzak et al. (Bloomington: Indiana University Press, I 996).

24 Bernard Knox, 'Introduction', to Oedipus the King, in Sophocles, The Three Theban Plays, translated by Robert Fagles, introductions and notes by Bernard Knox (London and New York: Penguin, I982), pp. I3 I-I 53 (p. I46).

25 Peter Hallward, Absolutely Postcolonial: Writing Between the Singular and the Specific (Manchester: Manchester University Press, 200I).

26 See Mark Epstein, Psychotherapy mithout the Self (New Haven and London: Yale University Press, 2007) and Dale Mathers, Self and No Self: Continuing the Dialogue between Buddhism and Psychotherapy (London: Routledge, 2009). 